\title{
VIABILITAS DAN VIRULENSI TUJUH BELAS TAHUN PENYIMPANAN Fusarium oxysporum Schlecht. f.sp. zingiberi Trujillo DALAM TANAH STERIL
}

\section{VIABILITY AND VIRULENCE OF SEVENTEEN YEARS PRESERVATION OF Fusarium oxysporum SCHLECHT. F.SP. zingiberi TRUJILLO IN STERILE SOILS}

\author{
Elvina Hapsari ${ }^{1}$, Loekas Soesanto ${ }^{1}$, Endang Mugiastuti ${ }^{1}$ \\ ${ }^{1}$ Fakultas Pertanian Universitas Jenderal Soedirman \\ Jalan Dr. Soeparno 73 Purwokerto Kode Pos 53122 Jawa Tengah \\ Korespondensi : lukassusanto26@gmail.com
}

\begin{abstract}
ABSTRAK
Koleksi dan penyimpanan mikroba diperlukan untuk penelitian lebih lanjut, sumber biodiversitas, koleksi, dan konservasi plasma nutfah mikroba. Salah satu teknik penyimpanan mikroba adalah dalam tanah steril. Penelitian ini bertujuan untuk mengetahui viabilitas dan virulensi beberapa isolat Fusarium oxysporum f.sp. zingiberi setelah disimpan selama tujuh belas tahun pada tanah steril. Rancangan yang digunakan adalah Rancangan Acak Lengkap dengan tiga ulangan dan 17 perlakuan, yaitu isolat $F$. oxysporum f.sp. zingiberi asal Magelang terdiri atas MBO1, MBO2, MSO1, MSO3, MSO4, MCO1, MCO2, MBM, MSH dan MSS, serta asal Purworejo, yaitu PBO1, PBO2, PPO1, $\mathrm{PKO} 2, \mathrm{PKO}$, PPH dan PBOSi. Variabel yang diamati adalah warna koloni, diameter koloni, mikrokonidium, makrokonidium, waktu pertumbuhan, kecepatan tumbuh, berat kering miselium, kerapatan konidium, masa inkubasi, luas serangan, selisih bobot, dan indeks sampah. Hasil penelitian menunjukkan bahwa semua isolat $F$. oxysporum f.sp. zingiberi asal Magelang dan Purworejo, yang telah disimpan dalam medium tanah steril selama tujuh belas tahun, masih tumbuh dengan baik pada medium PDA dan memenuhi cawan Petri pada umur 6-19 hari. Isolat $F$. oxysporum f.sp. zingiberi tersebut masih mampu menimbulkan gejala busuk rimpang jahe dengan masa inkubasi 11-21 hari setelah inokulasi. Rerata luas serangannya antara 2,07-2,65 $\mathrm{mm}^{2}$. Rerata luas serangan terbesar dan terkecil terdapat pada perlakuan PBOSi dan MSO4 masing-masing sebesar 2,65 dan 2,07 $\mathrm{mm}^{2}$ atau 49,00 dan 16,28 \% dibandingkan kontrol Rerata indeks sampah tertinggi dan terendah masing-masing terdapat pada PBO2 dan MCO1 sebesar 39,56 dan 18,70 g atau 129,00 dan 8,4 \% dibandingkan kontrol.
\end{abstract}

Kata kunci: Fusarium oxysporum f.sp. zingiberi, Penyimpanan, Rimpang Jahe, Tanah Steril

\begin{abstract}
Microbial collection and preservation is needed for further research, sources of biodiversity, collection, and conservation of microbial germplasm. One technique for preserving microbes is in sterile soil. The purpose of this study is knows determine the virulence and viability levels of Fusarium oxysporum f. sp. zingiberi from Magelang and Purworejo after being stored for 17 years in sterile soil medium. Completely Randomized Design was used with three replicates and 17 treatments consisted of $F$. oxysporum f.sp. zingiberi originated from Magelang, i.e., MBO1, MBO2, MSO1, MSO3, MSO4, MCO1, MCO2, MBM, MSH, and MSS, and from Purworejo, i.e., PBO1, PBO2, PPO1, $\mathrm{PKO}$, PKO3, PPH, and PBOSi. Variables observed were the colony color, colony diameter, microconidia, macroconidia, growth time, growth speed, dry weight of mycelium, conidia density, incubation period, attack area, weight difference, and waste index. The result showed that all isolates of $F$. oxysporum f.sp. zingiberi both from Magelang and Purworejo were able to grow well on PDA
\end{abstract}


and fully covered the Petridish at 6-19 days. F. oxysporum f. sp. zingiberi were still able to cause rhizome rot symptoms with an incubation period of 11-21 days after inoculation. The average attack area was between 2.07-2.65 mm2. The largest and smallest mean of attack area were found in PBOSi that is 2,65 and $2,07 \mathrm{~mm}^{2}$ or 49.00 and $16.28 \%$, respectively, compared to control. The highest and lowest waste index were found in the PBO2 and MCO1 as 39,56 and 18,70 g or 129 and $8.4 \%$, respectively, compared to control.

Key words: Fusarium oxysporum f.sp zingiberi, Ginger Rhizome, Preservation, Sterile Soil

\section{PENDAHULUAN}

Jahe (Zingiber officinale) merupakan salah satu rempah yang banyak digunakan untuk konsumsi dan juga untuk kesehatan. Selain itu, kandungan minyak atsiri jahe juga merupakan salah satu peluang usaha peningkatan nilai ekonomi jahe (Kaushal et al. 2017). Data Badan Pusat Statistik (2021) menunjukkan, bahwa produksi jahe mengalami penurunan dari tahun $2018 \mathrm{ke}$ tahun 2020, yaitu dari $207.411 .867,00 \mathrm{~kg}$ di tahun 2018 ke $183.517 .778,00 \mathrm{~kg}$ di tahun 2020 atau turun sebesar 11,52. Penurunan produksi jahe disebabkan oleh banyak faktor, salah satu di antaranya yang sangat penting, adalah penyakit busuk rimpang, yang disebabkan oleh jamur Fusarium oxysporum Schlecht. f.sp. zingiberi Trujillo (Li et al., 2014).

Jamur patogen $F$. oxysporum f.sp zingiberi merupakan jamur tular-tanah (Di et al., 2016). Li et al. (2014) menambahkan bahwa jahe yang terserang $F$. oxysporum f.sp. zingiberi menyebabkan rimpang jahe menjadi keriput sehingga kualitas jahe menurun. Fusarium sp. mampu bertahan hidup di dalam tanah dalam jangka waktu lama, bahkan dalam keadaan tanpa adanya tanaman inang (Pegg et al., 2019). Jamur ini masih diperlukan untuk pengkajian lebih lanjut, sehingga perlu dilakukan penyimpanan. Koleksi dan penyimpanan mikroba diperlukan untuk penelitian lebih lanjut, sumber biodiversitas, koleksi, dan konservasi plasma nutfah mikroba, sehingga apabila suatu saat diperlukan dapat diperoleh kembali (Priyanka et al., 2021). Salah satu teknik penyimpanan mikroba adalah dalam tanah steril (Ramírez et al., 2017). Teknik ini mempunyai beberapa keuntungan, yaitu biaya murah, penyimpanan pada suhu ruang, dan kestabilan genetika mikroba dapat dipertahankan. Jamur dapat bertahan hidup dengan baik pada tanah kering yang disimpan pada suhu ruang untuk waktu yang lama hingga 20 tahun atau lebih (Pegg et al., 2019).

Hasil penelitian sebelumnya menunjukkan bahwa $F$. oxysporum f.sp zingiberi yang disimpan dalam tanah setril selama enam tahun masih menunjukkan viabilitas dan virulensi yang tinggi (Riyadi et al., 2008). Oleh karena itu, dilakukan penelitian dengan tujuan untuk mengetahui daya tumbuh dan kevirulenan $F$. oxysporum f.sp. zingiberi isolat Magelang dan Purworejo setelah disimpan 17 tahun pada medium tanah steril.

\section{BAHAN DAN METODE}

\section{Penyiapan Inokulum $F$. oxysporum f.sp. zingiberi}

F. oxysporum f.sp. zingiberi yang telah disimpan dalam tanah steril di dalam botol selama tujuh belas tahun ditumbuhkan pada medium PDA yang telah disiapkan pada cawan Petri. Apabila F. oxysporum f.sp. zingiberi mampu tumbuh, isolat kemudian dimurnikan pada medium PDA yang diperkaya dengan streptomisin (Leslie et al., 2006), dan siap digunakan untuk penelitian lebih lanjut. Isolat $F$. oxysporum f.sp. zingiberi yang digunakan berasal dari 
Magelang terdiri atas sepuluh isolat, yaitu MBO1, MBO2, MSO1, MSO3, MSO4, MCO1, MCO2, MBM, MSH dan MSS; dan berasal dari Purworejo terdiri atas tujuh isolat, yaitu $\mathrm{PBO} 1, \mathrm{PBO} 2, \mathrm{PPO} 1, \mathrm{PKO}$, PKO3, PPH dan PBOSi.

\section{Penyiapan dan Inokulasi Rimpang Jahe}

Rimpang jahe dipilih dengan ukuran dan umur homogen, kemudian disterilkan permukaannya dengan cara direndam dalam larutan $\mathrm{NaOCl} 1 \%$ selama 3 menit. Selanjutnya, dibilas dengan air steril hingga beberapa kali, ditiriskan pada kertas saring steril dan siap digunakan (Nasehi et al., 2012). Permukaan rimpang jahe steril dilukai dengan jarum preparat steril (diameter luka 0,8-1,0 cm) dengan kedalaman $1 \mathrm{~mm}$ sebanyak \pm 30 luka tusukan dalam luasan 25 $\mathrm{mm}^{2}$, kemudian diinokulasi dengan satu tetes (kerapatan $10^{7}$ konidium/ml larutan) suspensi F. oxysporum f.sp. zingiberi dan ditutup dengan kapas lembap. Rimpang selanjutnya dimasukkan ke dalam kantong plastik, diikat, dan diinkubasi. Rancangan yang digunakan adalah Rancangan Acak Lengkap dengan 3 ulangan dan 18 perlakuan.

\section{Variabel yang Diamati}

Variabel yang diamati adalah pertumbuhan isolat pada medium PDA, pengamatan morfologi isolat terdiri atas daya tumbuh, kecepatan pertumbuhan, warna koloni, diameter koloni, makrokonidium, mikrokonidium, berat kering miselium, kerapatan konidium, masa inkubasi, luas serangan, selisih bobot, dan indeks sampah. Menurut Suprianto et al. (2020), pengukuran berat kering miselium dilakukan dengan menambahkan $10 \mathrm{ml} \mathrm{HCl}$ $1 \%$, lalu dipanaskan pada water bath hingga mencair, kemudian dituang pada kertas saring yang telah diketahui beratnya, dan disemprot dengan air steril untuk menghilangkan agar dan $\mathrm{HCl}$ yang masih melekat. Koloni jamur yang tertinggal pada kertas saring dikeringkan dalam inkubator pada suhu $30^{\circ} \mathrm{C}$ selama 24 jam kemudian ditimbang dua kali. Pertumbuhan $F$. oxysporum f.sp. zingiberi diketahui dengan mengukur diameter koloni dan kecepatan tumbuh jamur. Masa inkubasi dihitung sejak inokulasi patogen sampai munculnya gejala pertama dalam satuan hari setelah inokulasi (hsi). Luas serangan $F$. oxysporum f.sp. zingiberi pada rimpang diukur dengan menggunakan kertas millimeter blok dengan interval pengamatan dua hari sekali selama satu bulan. Selisih berat basah rimpang diperoleh dari berat rimpang sebelum inokulasi dikurangi berat rimpang di akhir pengamatan. Indeks sampah dihitung dengan menggunakan rumus:

Indeks sampah $=\frac{\text { berat jaringan sakit }}{\text { berat seluruhnya }}$

\section{Analisis Data}

Data yang diperoleh dari uji daya tumbuh dianalisis secara deskriptif, sedangkan dari uji in vivo dianalisis dengan menggunakan uji $\mathrm{F}$ untuk mengetahui pengaruh dari perlakuan. Apabila berbeda nyata, dilanjutkan dengan DMRT pada tingkat kesalahan 5\%.

\section{HASIL DAN PEMBAHASAN}

\section{Daya Tumbuh Isolat Fusarium oxysporum f.sp. zingiberi}

Semua isolat $F$. oxysporum f.sp. zingiberi yang telah disimpan dalam medium tanah steril selama tujuh belas tahun memperlihatkan kemampuan bertahan hidup yang baik. Hal ini menunjukkan bahwa isolat F. oxysporum f.sp. zingiberi tersebut masih memiliki viabilitas yang baik (Gambar 1). Tanah steril merupakan medium penyimpanan isolat Fusarium yang baik, jika ditinjau dari daya tahan hidupnya (Freire et al., 2016). Lebih lanjut Windels et al. (1988) menyatakan bahwa daya hidup isolat Fusarium yang disimpan dalam gel silika selama 3, 4 dan 5 mengalami penurunan, sedangkan yang disimpan dalam tanah steril nampak stabil. Daya tumbuh $F$. oxysporum f.sp. zingiberi yang masih baik setelah disimpan dalam tanah steril selama tujuh 
belas tahun mungkin terjadi karena jamur $F$. oxysporum f.sp. zingiberi memiliki struktur tahan yang dapat bertahan hidup cukup lama tanpa adanya inang serta keadaan lingkungan yang terkendali (De Cal et al., 2008).

Berdasarkan hasil pengamatan (Gambar 1), warna koloni $F$. oxysporum f.sp. zingiberi isolat Magelang dan Purworejo berwarna putih dan krem. Hal ini sesuai dengan Leslie et al. (2006) dan Aguilar-Hawod et al. (2020) yang menyatakan bahwa pada medium PDA koloni isolat Fusarium pada umumnya berwarna putih, yang semakin tua warna menjadi krem atau kuning pucat, atau dalam keadaan tertentu berwarna merah muda agak ungu. Ngittu et al. (2014) menambahkan bahwa warna koloni untuk setiap kelompok Fusarium spp. didominasi oleh warna putih, krem, merah muda dan ungu muda. Tipe koloni didominasi oleh tipe seperti kapas dan tipis. Pada masingmasing isolat Fusarium spp. terdapat sporodokim (Sari et al., 2017).

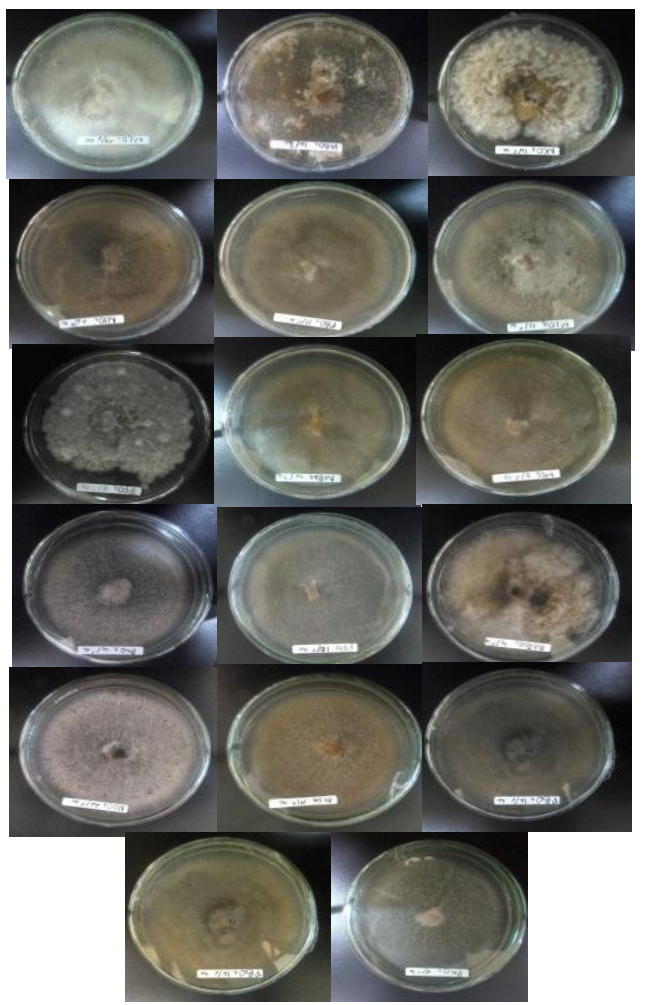

Gambar 1. Ketujuhbelas isolat $F$. Oxysporum f.sp. zingiberi asal Purworejo dan Magelang yang tumbuh di medium PDA (Sumber: dokumentasi pribadi).
Berdasarkan pengamatan menggunakan mikroskop (Gambar 2), bentuk makrokonidium untuk setiap isolat $F$. oxysporum f.sp. zingiberi terlihat berbentuk bulan sabit dengan 1-4 sekat, tetapi ada yang berbentuk panjang melengkung dengan ujung tumpul. Semua isolat $F$. oxysporum f.sp. zingiberi memiliki bentuk mikrokonidium sama yaitu oval. Mikrokonidium bersel tunggal, berbentuk oval sampai ginjal dan terbentuk pada false head, yaitu kumpulan mikrokonidum dengan monofialid pendek (Fourie et al., 2011). Makrokondium berbentuk sabit yang ramping, dinding sel tebal dan halus dengan apikal sel yang runcing dan menukik.

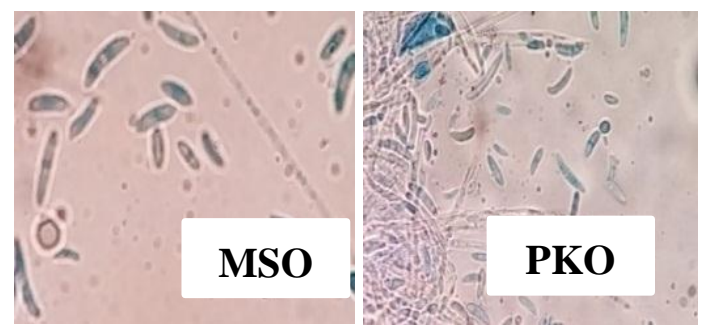

Gambar 2. Bentuk konidium F. oxysporum.

(Sumber: Dokumentasi pribadi).

Berdasarkan hasil pengamatan (Gambar 3), diameter koloni tertinggi saat jamur berumur 3 hari dalam medium PDA yaitu isolat $\mathrm{PKO} 2$ yaitu sebesar $67 \mathrm{~mm}$ dan untuk diameter koloni terendah terdapat pada $\mathrm{MBO} 2$ dan $\mathrm{PBO} 1$ yaitu sebesar $23 \mathrm{~mm}$. Isolat $F$. oxysporum f.sp. zingiberi yang ditumbuhkan pada medium PDA mempunyai viabilitas yang berbeda. Waktu pertumbuhan selaras dengan kecepatan pertumbuhannya . Berdasarkan hasil analisis (Tabel 1), kecepatan tumbuh isolat tertinggi terlihat pada isolat $\mathrm{PKO}$, MSO1, dan MBM dengan kecepatan tumbuh $15 \mathrm{~mm} / \mathrm{hari}$, sehingga memiliki waktu pertumbuhan untuk memenuhi cawan Petri yaitu 6 hari, sedangkan kecepatan tumbuh memenuhi cawan Petri terlambat nampak pada isolat $\mathrm{MBO} 2, \mathrm{MCO} 2$ dan PBO1, dengan kecepatan tumbuh 4,7 $\mathrm{mm} /$ hari, sehingga waktu pertumbuhan untuk memenuhi cawan Petri yaitu 19 hari. 


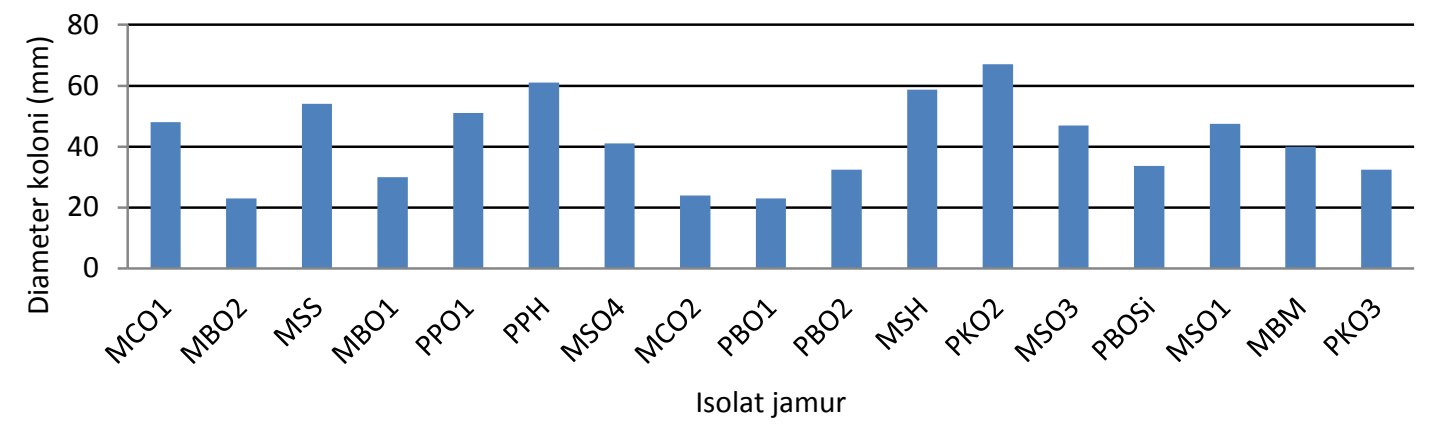

Gambar 3. Diameter koloni F. oxysporum f.sp. zingiberi saat berumur 3 hari.

Hal tersebut diduga terjadi karena jamur $F$. oxysporum f.sp. zingiberi yang telah disimpan pada medium tanah steril selama tujuh belas tahun mengalami perubahan fisiologi, sehingga membutuhkan waktu yang lama untuk beradaptasi apabila ditumbuhkan pada medium baru. Selain itu, faktor penyebab turunnya viabilitas jamur setelah penyimpanan adalah faktor teknis berupa suhu saat penyimpanan isolat. Hal ini sesuai dengan pendapat Guimarães et al. (2014), bahwa penyimpanan jamur dalam tanah steril pada jangka waktu yang lama dapat menyebabkan terjadinya perubahan fisiologi, morfologi, dan keragaman jamur. Porter et al. (2015) menyatakan bahwa suhu penyimpanan akan berpengaruh terhadap keberlangsungan hidup spora jamur, yang akan mempengaruhi umur simpan jamur.

Tabel 1. Waktu Pertumbuhan, kecepatan tumbuh, berat kering miselium dan kerapatan konidium isolat $F$. oxysporum f.sp. zingiberi yang telah disimpan dalam medium tanah steril selama tujuh belas tahun

\begin{tabular}{llccll}
\hline No & Isolat & $\begin{array}{l}\text { Waktu } \\
\text { Pertumbuhan } \\
\text { (hari) }\end{array}$ & $\begin{array}{l}\text { Kecepatan } \\
\text { Tumbuh }(\mathrm{cm} \\
\text { /hari) }\end{array}$ & $\begin{array}{l}\text { Berat Kering } \\
\text { Misellium }(\mathrm{g})\end{array}$ & $\begin{array}{l}\text { Kerapatan } \\
\text { Konidium } \\
\text { (konidium/ml) }\end{array}$ \\
\hline 1 & MCO1 & $11 \mathrm{e}$ & $0,82 \mathrm{~b}$ & $0,24 \mathrm{de}$ & $1,67 \times 10^{6} \mathrm{bc}$ \\
2 & MBO2 & $19 \mathrm{~g}$ & $0,47 \mathrm{a}$ & $0,21 \mathrm{bcd}$ & $1,05 \times 10^{6} \mathrm{a}$ \\
3 & MSS & $7 \mathrm{ab}$ & $1,28 \mathrm{de}$ & $0,13 \mathrm{a}$ & $2,23 \times 10^{6} \mathrm{def}$ \\
4 & MBO1 & $14 \mathrm{f}$ & $0,63 \mathrm{ab}$ & $0,12 \mathrm{a}$ & $2,733 \times 10^{6} \mathrm{f}$ \\
5 & PPO1 & $8 \mathrm{bc}$ & $1,12 \mathrm{~cd}$ & $0,22 \mathrm{~cd}$ & $1,25 \times 10^{6} \mathrm{ab}$ \\
6 & PPH & $8 \mathrm{bc}$ & $1,12 \mathrm{~cd}$ & $0,26 \mathrm{de}$ & $1,73 \times 10^{6} \mathrm{bcd}$ \\
7 & MSO4 & $10 \mathrm{de}$ & $0,90 \mathrm{bc}$ & $0,26 \mathrm{de}$ & $1,46 \times 10^{6} \mathrm{abc}$ \\
8 & MCO2 & $19 \mathrm{~g}$ & $0,47 \mathrm{a}$ & $0,22 \mathrm{~cd}$ & $2,35 \times 10^{6} \mathrm{ef}$ \\
9 & PBO1 & $19 \mathrm{~g}$ & $0,47 \mathrm{a}$ & $0,34 \mathrm{fg}$ & $3,70 \times 10^{6} \mathrm{~g}$ \\
10 & PBO2 & $8 \mathrm{bc}$ & $1,12 \mathrm{~cd}$ & $0,24 \mathrm{de}$ & $1,40 \times 10^{6} \mathrm{ab}$ \\
11 & MSH & $7 \mathrm{ab}$ & $1,28 \mathrm{de}$ & $0,21 \mathrm{bcd}$ & $1,38 \times 10^{6} \mathrm{ab}$ \\
12 & PKO2 & $6 \mathrm{a}$ & $1,50 \mathrm{e}$ & $0,25 \mathrm{de}$ & $1,76 \times 10^{6} \mathrm{bcd}$ \\
13 & MSO3 & $8 \mathrm{bc}$ & $1,12 \mathrm{~cd}$ & $0,28 \mathrm{e}$ & $1,51 \times 10^{6} \mathrm{abc}$ \\
14 & PBOSi & $11 \mathrm{e}$ & $0,81 \mathrm{~b}$ & $0,38 \mathrm{~g}$ & $2,01 \times 10^{6} \mathrm{cde}$ \\
15 & MSO1 & $6 \mathrm{a}$ & $1,50 \mathrm{e}$ & $0,16 \mathrm{ab}$ & $1,50 \times 10^{6} \mathrm{abc}$ \\
16 & MBM & $6 \mathrm{a}$ & $1,50 \mathrm{e}$ & $0,29 \mathrm{ef}$ & $1,60 \times 10^{6} \mathrm{abc}$ \\
17 & PKO3 & $9 \mathrm{~cd}$ & $1,33 \mathrm{de}$ & $0,17 \mathrm{abc}$ & $1,50 \times 10^{6} \mathrm{abc}$ \\
\hline
\end{tabular}

Keterangan: Angka yang diikuti huruf sama pada kolom yang sama menunjukkan tidak berbeda nyata menurut DMRT 5\%. 
Pengujian pada variabel pengamatan berat kering miselium $F$. oxysporum f.sp. zingiberi (Tabel 1) menunjukkan hasil yang berbeda nyata. Rerata berat kering misellium isolat $F$. oxysporum f.sp. zingiberi terbesar terdapat pada isolat asal Purworejo yaitu PBOSi sebesar 0,38 $\mathrm{g}$ dan terkecil terdapat pada isolat asal Magelang yaitu MBO1 sebesar 0,12 g. Hal ini dapat dilihat dari pertumbuhan jamur pada cawan Petri bahwa koloni isolat jamur PBOSi tebal, sehingga memiliki berat kering miselium yang besar, sedangkan untuk pertumbuhan isolat MBO1 terlihat tipis, sehingga berat kering miseliumnya kecil. Hal ini menunjukkan bahwa semakin kecil berat kering miselium jamur, daya tumbuh jamur di medium PDA juga rendah. Perbedaan ini diduga terjadi karena adanya variasi genetika antar-isolat jamur, sehingga menghasilkan ketebalan koloni yang beragam. Hal ini sesuai dengan Borman et al. (2006), yang menyatakan bahwa penyimpanan jamur dalam waktu yang lama dapat menyebabkan perubahan yaitu proliferasi produksi miselium atau produksi miselium udara yang berlebihan dan penurunan konidiogenesis.

Berdasarkan hasil pengamatan, kerapatan konidium isolat $F$. oxysporum f.sp. zingiberi sangat beragam (Tabel 1). Kerapatan konidium tertinggi terdapat pada isolat PBO1 sebesar 3,7 x $10^{6}$ konidium $/ \mathrm{ml}$ dan kerapatan konidium terendah terdapat pada isolat $\mathrm{MBO} 2$ yaitu 1,05 x $10^{6}$ konidium $/ \mathrm{ml}$. Keragaman kerapatan konidium diduga terjadi karena keberagaman genetika $F$. oxysporum f.sp. zingiberi. Hal ini sesuai dengan pernyataan Riyadi (2008) bahwa adanya kepadatan konidium yang berbeda antar-isolat menunjukkan tingginya keragaman genetika $F$. oxysporum f.sp. zingiberi. Selain disebabkan oleh sifat genetika, perbedaan antar-isolat juga ditentukan oleh kondisi lingkungan, seperti suhu tanah. Hal ini sesuai dengan pernyataan Pietikäinen et al.(2005), bahwa suhu tanah merupakan faktor penting yang mengatur laju pertumbuhan mikroba tanah.

Hasil perhitungan kepadatan konidium (Tabel 1) jamur menunjukkan bahwa kepadatan konidium $F$. oxysporum f.sp. zingiberi tidak selaras dengan kecepatan pertumbuhan dan berat kering miseliumnya. Hal ini diduga karena masing-masing isolat mempunyai karakter yang berbeda yang disebabkan oleh perbedaan genetika isolat jamur. Menurut Guimarães et al. (2014), perbedaan tingkat viabilitas antar-isolat dapat disebabkan adanya perbedaan variasi jenis isolat yang digunakan yang akan memengaruhi perbedaan karakter fisiologis dan morfologis, termasuk di dalamnya kemampuan viabilitas dan tingkat toleransi terhadap adanya perubahan lingkungan.

\section{Gejala Penyakit}

Berdasarkan hasil pengamatan, isolat $F$. oxysporum f.sp. zingiberi yang telah disimpan selama tujuh belas tahun masih mampu untuk menimbulkan gejala busuk rimpang setelah diinokulasi pada rimpang jahe. Pengamatan secara visual terhadap rimpang jahe yang telah diinokulasi $F$. oxysporum f.sp. zingiberi menunjukkan gejala busuk pada rimpang jahe berupa cekungan pada rimpang, berkeriput dan terdapat miselium jamur serta busuk kering. Hal ini sesuai dengan Wahyu et al. (2012), bahwa semua isolat $F$. oxysporum f.sp. zingiberi asal Temanggung dan Boyolali yang telah disimpan dalam tanah steril selama tiga tahun, dapat menimbulkan gejala busuk kering rimpang jahe dengan gejala adanya bercak coklat tua, cekung, dan mengering atau berkerut. Berdasarkan hasil penelitian, perlakuan kontrol juga menunjukkan gejala penyakit yang sama, hal ini diduga terjadi karena kontaminasi jamur patogen saat perlakuan inokulasi. 
Tabel 2. Masa inkubasi, luas serangan, selisih bobot basah dan indeks sampah

\begin{tabular}{ccccc}
\hline Perlakuan & $\begin{array}{c}\text { Masa Inkubasi } \\
(\mathrm{hsi})\end{array}$ & $\begin{array}{c}\text { Luas Serangan } \\
\left(\mathrm{mm}^{2}\right)\end{array}$ & $\begin{array}{c}\text { Selisih Bobot } \\
\text { Basah }(\mathrm{g})\end{array}$ & $\begin{array}{c}\text { Indeks Sampah } \\
(\mathrm{g})\end{array}$ \\
\hline Kontrol & $27,66 \mathrm{c}$ & $1,78 \mathrm{a}$ & $1,25 \mathrm{a}$ & $17,24 \mathrm{a}$ \\
MBM & $16,33 \mathrm{ab}$ & $2,44 \mathrm{~b}$ & $1,45 \mathrm{a}$ & $26,26 \mathrm{bcde}$ \\
MBO1 & $21,66 \mathrm{bc}$ & $2,24 \mathrm{ab}$ & $1,30 \mathrm{a}$ & $19,10 \mathrm{ab}$ \\
MBO2 & $21,66 \mathrm{bc}$ & $2,13 \mathrm{ab}$ & $1,39 \mathrm{a}$ & $26,32 \mathrm{bcde}$ \\
MCO1 & $20,33 \mathrm{abc}$ & $2,28 \mathrm{ab}$ & $1,28 \mathrm{a}$ & $18,7 \mathrm{ab}$ \\
MCO2 & $20,33 \mathrm{abc}$ & $2,51 \mathrm{~b}$ & $1,29 \mathrm{a}$ & $34,883 \mathrm{ef}$ \\
MSH & $17 \mathrm{ab}$ & $2,312 \mathrm{ab}$ & $1,25 \mathrm{a}$ & $27,53 \mathrm{bcde}$ \\
MSO1 & $11,66 \mathrm{a}$ & $2,60 \mathrm{~b}$ & $1,26 \mathrm{a}$ & $30,54 \mathrm{cdef}$ \\
MSO3 & $13 \mathrm{ab}$ & $2,42 \mathrm{ab}$ & $1,40 \mathrm{a}$ & $28,12 \mathrm{cde}$ \\
MSO4 & $21 \mathrm{bc}$ & $2,07 \mathrm{ab}$ & $1,24 \mathrm{a}$ & $31,94 \mathrm{def}$ \\
MSS & $17 \mathrm{ab}$ & $2,40 \mathrm{ab}$ & $1,31 \mathrm{a}$ & $32,99 \mathrm{def}$ \\
PBO1 & $17 \mathrm{ab}$ & $2,46 \mathrm{~b}$ & $1,33 \mathrm{a}$ & $25,07 \mathrm{abcd}$ \\
PBO2 & $15 \mathrm{ab}$ & $2,64 \mathrm{~b}$ & $1,33 \mathrm{a}$ & $39,556 \mathrm{f}$ \\
PBSOi & $14,33 \mathrm{ab}$ & $2,654 \mathrm{~b}$ & $1,21 \mathrm{a}$ & $22,87 \mathrm{abc}$ \\
PKO2 & $17,66 \mathrm{bc}$ & $2,36 \mathrm{ab}$ & $1,33 \mathrm{a}$ & $36,876 \mathrm{f}$ \\
PKO3 & $17,66 \mathrm{ab}$ & $2,23 \mathrm{ab}$ & $1,22 \mathrm{a}$ & $26,35 \mathrm{bcde}$ \\
PPH & $16,33 \mathrm{ab}$ & $2,63 \mathrm{~b}$ & $1,24 \mathrm{a}$ & $22,23 \mathrm{abc}$ \\
PPO1 & $21 \mathrm{bc}$ & $2,18 \mathrm{ab}$ & $1,28 \mathrm{a}$ & $22,79 \mathrm{abc}$ \\
\hline
\end{tabular}

Keterangan: Angka yang didampingi huruf yang sama pada kolom dan baris yang sama berpengaruh tidak nyata menurut DMRT taraf 5\%.

\section{Masa Inkubasi Penyakit}

Hasil analisis menunjukkan bahwa masa inkubasi tercepat terjadi pada isolat MSO1 yaitu 11 hsi dan untuk masa inkubasi terlambat terjadi pada isolat MBO1, MSO4, PPO1 dan MBO2 yaitu 21 hsi (Tabel 2). Perbedaan masa inkubasi tersebut erat kaitannya dengan kecepatan pertumbuhan. Isolat dengan kecepatan pertumbuhan terbesar terdapat pada isolat MSO1 yaitu sebesar $15 \mathrm{~mm} / \mathrm{hari}$. Isolat dengan kecepatan pertumbuhan tertinggi mempunyai masa inkubasi yang tercepat dalam menimbulkan gejala. Selain itu perbedaan masa inkubasi juga diduga terjadi karena adanya perbedaan proses adaptasi yang dibutuhkan pada masing-masing isolat akibat perbedaan genetika isolat jamur serta adanya berbagai faktor lain, yang dapat memengaruhi proses infeksi dan perkembangan penyakit seperti kondisi lingkungan yang mendukung untuk munculnya gejala. Hal ini sesuai dengan Ambar et al. (2010), yang menyatakan bahwa terjadinya perbedaan tingkat virulensi setiap isolat Fusarium disebabkan oleh kemampuan isolat mengenali inangnya lebih awal. Menurut Sari et al. (2017), cepat atau lambatnya masa inkubasi juga ditentukan oleh kemampuan patogen untuk menginfeksi dengan mengeluarkan enzim pengurai atau toksin.

\section{Luas Serangan $F$. oxysporum f.sp. zingiberi pada Rimpang}

Berdasarkan hasil analisis pada Tabel 2 diketahui bahwa tidak semua luas serangan yang diakibatkan $F$. oxysporum f.sp. zingiberi pada jahe gajah menunjukkan beda nyata terhadap kontrol. Hal ini menunjukkan bahwa tidak semua isolat $F$. oxysporum f.sp. zingiberi mempunyai keganasan yang berbeda. Beberapa isolat $F$. oxysporum f.sp. zingiberi yang telah disimpan selama 17 
tahun pada medium tanah steril masih dapat mempunyai keganasan yang sama dalam menyerang rimpang jahe, dengan ditunjukkannya gejala yang terdapat pada rimpang jahe. Luas serangan terbesar ditunjukkan oleh isolat asal Purworejo yaitu PBOSi sebesar 2,65 $\mathrm{mm}^{2}$ atau $49 \%$ lebih besar dibandingkan dengan perlakuan kontrol yang hanya mempunyai nilai 1,78 $\mathrm{mm}^{2}$ (Tabel 2), sedangkan untuk luas serangan terkecil terlihat pada isolat asal Magelang yaitu MSO4 sebesar 2,07 $\mathrm{mm}^{2}$ atau $16,28 \%$ lebih besar dibandingkan kontrol yang hanya memiliki nilai $1,78 \mathrm{~mm}^{2}$. Isolat MSO4 memiliki virulensi paling rendah dibandingkan isolat lainnya yang ditandai dengan masa inkubasi lebih lambat yaitu 21 hsi.

Hal ini menunjukkan bahwa luas serangan berkaitan dengan masa inkubasi patogen, karena patogen dengan masa inkubasi cepat mampu menimbulkan gejala penyakit yang tinggi. Cahyaningrum et al. (2017) menyatakan bahwa lamanya masa inkubasi memengaruhi perkembangan patogen dalam menyebabkan kerusakan pada rimpang jahe. Leclerc et al. (2014) juga menyatakan bahwa masa inkubasi yang panjang menyebabkan kemungkinan tidak munculnya gejala penyakit dan sebaliknya.

Perbedaan luas serangan disebabkan oleh kondisi lingkungan yang menguntungkan dan tingkat patogenitas. Apabila patogen dengan tingkat patogenitas tinggi menyerang pada inang rentan pada saat kondisi lingkungan yang mendukung, maka hal tersebut akan memperluas gejala penyakit yang ditimbulkan. Akan tetapi apabila salah satu faktor tidak sesuai, maka terjadinya penyakit akan terhambat. Hal tersebut sesuai dengan Riyadi et al. (2008), yang menyatakan bahwa untuk keberhasilan suatu infeksi patogen terhadap inang tidak cukup hanya dengan terjadinya kontak antara patogen dengan tumbuhan inang, tetapi beberapa kondisi lain harus dalam tingkat patogenitasnya tinggi. Nesic et al. (2014) dan Perincherry et al. (2019) menambahkan bahwa jamur Fusarium menghasilkan toksin yang memengaruhi kelenturan selaput sel dan merusak metabolisme sel tanaman. Isolat yang berbeda akan menyebabkan laju pertumbuhan, keganasan dan kolonisasi yang berbeda.

\section{Selisih Bobot Basah Rimpang}

Semua perlakuan menunjukkan terjadinya penurunan berat berat basah rimpang sebesar 15\% dibandingkan dengan kontrol serta terjadi perubahan morfologi. Hasil analisis statistika terhadap selisih bobot basah rimpang menunjukkan tidak berbeda nyata pada semua perlakuan (Tabel 2). Hal tersebut akan mengakibatkan tidak adanya perbedaan kemampuan dalam perbanyakan diri dan proses infeksi ke jaringan inang, yang menyebabkan lambat atau cepatnya pembusukan dan pengerutan inang atau rimpang. Hal ini diduga terjadi karena adanya kemampuan masing-masing isolat menginfeksi inang dan proses metabolisme dari rimpang jahe, seperti respirasi yang terjadi selama penelitian, yang antara lain ditunjukkan adanya uap-uap air, sehingga mengakibatkan turunnya kadar air dalam masing-masing rimpang jahe yang memengaruhi bobot rimpang jahe. Suhu dan kelembapan sekitar penelitian yaitu $31^{\circ} \mathrm{C}$ dan $72 \%$. Hal ini sesuai dengan Riyadi (2008), yang menyatakan bahwa selisih berat basah disebabkan oleh perbedaan kemampuan tiap-tiap isolat dalam perbanyakan diri dan proses infeksi pada jaringan inang. Menurut Li et al. (2014), penyakit busuk rimpang yang disebabkan oleh $F$. oxysporum f.sp. zingiberi menyebabkan rimpang mengerut dan berkeriput yang dapat mengakibatkan penurunan bobot rimpang basah serta merubah morfologi rimpang. 


\section{Indeks Sampah}

Hasil indeks sampah juga tidak berkaitan dengan masa inkubasi, luas serangan, dan selisih bobot basah rimpang yang diinokulasi $F$. oxysporum f.sp. zingiberi (Tabel 2). Hal ini diduga karena perbedaan kemampuan masing-masing isolat dalam menginfeksi rimpang dan adanya faktor yang memengaruhi pertumbuhan dan perkembangan penyakit. Menurut Velásquez et al. (2018), perkembangan gejala ditentukan oleh faktor patogen yang virulen, ketahanan tanaman inang terhadap ras patogen yang menginfeksi, dan kesesuaian kondisi lingkungan. Menurut Soesanto (2020), kehilangan pascapanen baik secara kualitatif maupun kuantitatif disebabkan oleh serangan jamur atau bakteri patogen. Bahkan dari presentase infeksi yang relatif kecil dapat menyebabkan kehilangan produk yang besar dan mengakibatkan kerugian yang besar.

\section{SIMPULAN}

Semua isolat $F$. oxysporum f.sp. zingiberi asal Magelang dan Purworejo, yang telah disimpan dalam medium tanah steril selama tujuh belas tahun, masih tumbuh dengan baik pada medium PDA dan memenuhi cawan Petri pada umur 6-19 hari. Isolat $F$. oxysporum f.sp. zingiberi tersebut masih mampu menimbulkan gejala busuk rimpang jahe dengan masa inkubasi 11-21 hari setelah inokulasi. Rerata luas serangannya antara 2,07-2,65 mm2. Rerata luas serangan terbesar dan terkecil terdapat pada perlakuan PBOSi dan MSO4 masing-masing sebesar 2,65 dan 2,07 $\mathrm{mm} 2$ atau 49,00 dan 16,28\% dibandingkan kontrol Rerata indeks sampah tertinggi dan terendah masing-masing terdapat pada $\mathrm{PBO} 2$ dan MCO1 sebesar 39,56 dan $18,70 \mathrm{~g}$ atau 129,00 dan $8,4 \%$ dibandingkan kontrol.

\section{DAFTAR PUSTAKA}

Aguilar-Hawod, K.G.I., de la Cueva, F.M., \& Cumagun, C.J.R. (2020). Genetic diversity of Fusarium oxysporum f. sp. cubense causing panama wilt of banana in the Philippines. Pathogens 9: 32. Doi:10.3390/pathogens9010032.

Ambar, A.Z., Priyatmojo, A., Hadisutrisno, B., \& Pusposendjojo, N. (2010). Virulensi 9 isolat Fusarium oxysporum f.sp. lycopersici dan perkembangan gejala layu fusarium pada dua varietas tomat di rumah kaca. Agrin 14(2): 89-96.

Badan Pusat Statistik. (2021). Statistika Tanaman Biofarmaka Indonesia (Obat) 2018-2020. Badan Pusat Statistik. Jakarta.

https://www.bps.go.id/indicator/55/63/1/ produksi-tanaman-biofarmaka-obat.html [11 September 2021].

Borman, A.M., Szekely, A., Campbell, C.K., \& Johnson, E.M. (2006). Evaluation of the viability of pathogenic filamentous fungi after prolonged storage in sterile water and review of recent published studies on storage methods. Mycopathologia 161: 361-368. DOI: 10.1007/s11046-006-0023-z.

Cahyaningrum, H., Prihatiningsih, N. \& Soedarmono. (2017). Intensitas dan luas serangan beberapa isolat Fusarium oxysporum f.sp. zingiberi pada jahe Gajah. Jurnal Perlindungan Tanaman Indonesia 21 (1): 16-22.

De Cal, A., Pascual, S., \& Melgarejo, P. (2008). Infectivity of chlamydospores vs microconidia of Fusarium oxysporum f.sp. lycopersici on tomato. Journal of Phytopathology 145(5-6): 231-233. DOI: 10.1111/j.1439-0434.1997.tb00391.x.

Di, X., Takken, F.L.W., \& Tintor, N. (2016). How phytohormones shape interactions between plants and the soil-borne fungus Fusarium oxysporum. Front. Plant Sci. 7: 170. Doi: 10.3389/fpls.2016.00170. 
Fourie, G., Steenkampa, E.T., Ploetzb, R.C., Gordonc, T.R., \& Viljoen, A. (2011). Current status of the taxonomic position of Fusarium oxysporum formae specialis cubense within the Fusarium oxysporum complex. Infection, Genetics and Evolution 11(3): 533-542. DOI: 10.1016/j.meegid.2011.01.012.

Freire, A.K.L., Bentes, A.S., Sampaio, I.L., de Lima, A.M., Botineli, L.F., da Rocha, L.C., de Souza, J.B., \& de Souza, Ã\%o. S. (2016). Availability and morphological characteristics of endophytic fungi held in different methods of preservation. Scientific Research and Essays 11(6): 7679. Doi: 10.5897/SRE2013.5696.

Guimarães, L.C., Fernandes, A.P., Chalfoun, S.M., \& Batista, L.R. (2014). Methods to preserve potentially toxigenic fungi. Braz. J. Microbiol. 45 (1). Doi: 10.1590/S151783822014000100007.

Kaushal, M., Gupta, A., Vaidya, D., \& Gupta, M. (2017). Postharvest management and value addition of ginger (Zingiber officinale Roscoe): A review. International Journal of Environment, Agriculture and Biotechnology (IJEAB) 2(2): 397-412. Doi: 10.22161/ijeab/2.1.50.

Leclerc, M., Doré, T., Gilligan, C.A., Lucas, P., \& Filipe, J.A.N. (2014). Estimating the delay between host infection and disease (incubation period) and assessing its significance to the epidemiology of plant diseases. PLoS ONE 9(1): e86568. Doi:10.1371/journal.pone.0086568.

Leslie, J.F., Summerell, B.A., \& Bullock, S. (2006). The Fusarium Laboratory Manual. Blackwell Publishing Professional, Lowa.

Li, Y., Chi, L.D., Mao, L.G., Yan, D.D., Wu, Z.F., Ma, T.T., Guo, M.X., Wang, Q.X., Ouyang, C.B., \& Cao, A.C. (2014). First report of ginger rhizome rot caused by Fusarium oxysporum in China. Plant
Dis. 98(2): 282. Doi: 10.1094/PDIS-0713-0729-PDN.

Nasehi, A., Kadir, J., Abidin, M.A.Z., Wong, M.-Y., \& Abed-Ashtiani, F. (2012). First report of gray leaf spot on pepper caused by Stemphylium solani in Malaysia. Plant Disease 96(8): 1227. DOI: 10.1094/PDIS-03-12-0262-PDN.

Nesic, K., Ivanovic, S., \& Nesic, V. (2014). Fusarial toxins: secondary metabolites of Fusarium fungi. Rev Environ Contam Toxicol. 228: 101-20. Doi: 10.1007/9783-319-01619-1_5.

Ngittu, Y. (2014). Identifikasi genus Fusarium yang menginfeksi eceng gondok (Eichhornia crassipes) di Danau Tondano. Jurnal Ilmiah Farmasi. UNSRAT. 3 (3).

Pegg, K.G., Coates, L.M., O’Neill, W.T., \& Turner, D.W. (2019). The epidemiology of fusarium wilt of banana. Front. Plant Sci. 10: 1395. DOI=10.3389/fpls.2019.01395.

Perincherry, L., Lalak-Kańczugowska, J., \& Stępień, L. (2019). Fusarium-produced mycotoxins in plant-pathogen interactions. Toxins (Basel). 11(11): 664. Doi: 10.3390/toxins11110664.

Pietikäinen, J., Pettersson, M., \& Bååth, E. (2005). Comparison of temperature effects on soil respiration and bacterial and fungal growth rates. FEMS Microbiology Ecology 52(1): 49-58. DOI: 10.1016/j.femsec.2004.10.002.

Porter, L.D., Pasche, J.S., Chen, W., \& Harveson, R.M. (2015). Isolation, identification, storage, pathogenicity tests, hosts, and geographic range of Fusarium solani f.sp. pisi causing fusarium root rot of pea. Plant Health Progress, 16(3): 136-145. Doi: 10.1094/PHP-DG-15-0013.

Priyanka, V., Kumar, R., Dhaliwal, I., \& Kaushik, P. (2021). Germplasm conservation: instrumental in agricultural 
biodiversity-A Review. Sustainability 13(12): $\quad 6743 . \quad$ DOI: 10.3390/su13126743.

Ramírez, M., Muñoz, A., López-Piñeiro, A., Ángel Albarrán, A., Peña, D., Nunes, J.M.R., Gama, J., \& Loures, L. (2017). Evaluation of the microbial viability of soil samples from maize crops in freezestorage under different management conditions in a semi-arid climate. Sustainability $\quad 9: \quad 690$. Doi:10.3390/su9050690.

Riyadi, S. A., Soesanto, L. \& Kustantinah. (2008). Virulensi Fusarium oxysporum f.sp. Zingiberi isolat Boyolali dan Temanggung setelah disimpan enam tahun dalam tanah steril. Jurnal Perlindungan Tanaman Indonesia 14(2): 80-85. Doi: 10.22146/jpti.11891.

Sari, W., Suryo, W., Ali, N., Abdul, M., \& Roedhy, P. (2017). Keanekaragaman dan patogenitas Fusarium spp. asal beberapa kultivar pisang. Jurnal Fitopatologi Indoonesia 13 (6): 216. Doi: 10.14692/jfi.13.6.216.

Soesanto, L. (2020). Penyakit Pascapanen. Lily Publisher, Yogyakarta.

Suprianto, Purwanto, Poromarto, S.H. \& Supyani. (2020). Evaluation of in vitro antagonistic activity of fungi from peatlands against Ganoderma species under acidic condition. Biodiversitas 21(7): $\quad 2935-2945 . \quad$ DOI: $10.13057 /$ biodiv/d210709.

Velásquez, A.C., Castroverde, C.D., \& He, S.Y. (2018). Plant-pathogen warfare under changing climate conditions. Current Biology 28(10): R619-R634. DOI: 10.1016/j.cub.2018.03.054.

Wahyu, H.S.N., L. Soesanto, dan Kustantinah. 2012. Keagresifan beberapa isolat Fusarium oxysporum f. sp. zingiberi asal Temanggung dan Boyolali setelah penyimpanan dalam tanah steril. Jurnal Fitopatologi Indonesia 8(6):170176. http://journal.ipb.ac.id/index.php/jfiti/art icle/view/6992.

Windels, C.E., Burnes, P.M. \& Kommendahl, T. (1988). Five-year preservation of Fusarium species on silica gels and soil. Phytopathology 78: 107-109. DOI: 10.1094/Phyto-78-107. 